\title{
COMMUNITY ENGAGEMENT WITH URBAN RIVER IMPROVEMENT: THE CASE OF YOGYAKARTA CITY (Melibatkan Masyarakat dalam Memperbaiki Lingkungan Sungai Perkotaan : Kasus Kota Yogyakarta)
}

\author{
Hari Kusnanto*, Suprapto Dibyosaputro, Suwarno Hadisusanto, and Sri Puji Saraswati \\ *Center for Environmental Studies, Universitas Gadjah Mada \\ Jl. Lingkungan Budaya, Sekip Utara Yogyakarta, 55281.
}

*Corresponding author. Tel: 0811293649. Email: harikusnanto@yahoo.com.

Diterima: 21 Januari 2016

Disetujui: 31 Juli 2016

\begin{abstract}
The restoration of urban rivers has shifted from predominantly physical and ecological to community oriented social and economic improvement. Community engagement is needed in the people approach of development. Information sharing and public consultation are not enough. A case study among the riverside communities living in Yogyakarta city indicated that these communities need to move out of poverty and destitution through coaching and mentoring by various experts, and at the same time they would assure the ecosystem functioning of urban rivers..
\end{abstract}

Keywords: community engagement, riverside communities, urban rivers, Yogyakarta city.

\begin{abstract}
Abstrak
Restorasi sungai-sungai perkotaan telah bergeser dari peningkatan fisik dan ekologis menjadi lebih berorientasi pada sosial dan ekonomi. Keterlibatan masyarakat dibutuhkan dalam pendekatan manusiawi pembangunan. Pemberian informasi dan konsultasi public tidak cukup studi kasus pada komunitas-komunitas yang hidup di pinggir sungai di kota Yogyakarta menunjukkan bahwa komunitas tersebut perlu mengentaskan diri dari kemiskinan dan keterbelaknagn dengan bantuan ahli, dan pada saat yang sama menjaga fungsi ekosistem sungai-sungai perkotaan.
\end{abstract}

Kata kunci: sungai perkotaan, masyarakat pinggir sungai, keterlibatan masyarakat, kota Yogyakarta.

\section{INTRODUCTION}

Urban development altered the quantity and quality of urban water bodies (Lange et al., 2015). Larger amount of impervious cover due to building and other infrastructure development, removal of vegetation and soil, construction of drainage networks, led to increased runoff to creeks and rivers. Urban flooding becomes more frequent because the needed capacity to drain away high volumes of rain is lacking (Tingsanchali, 2012). Water running from the impervious cover tends to carry gasoline, motor oil, trash, fertilizer, pesticide and other pollutants (Frazer, 2005), which may seriously deteriorate the quality of streams and rivers.

Cities have attracted migrants from rural areas, with an increasing intensity during the past few decades. These migrants are less educated and do not have necessary skills to work in the formal sector $(\mathrm{Lu}, 2010)$. The urban infrastructure and services are lacking to support the influx of migrants, usually less educated and poor. This is particularly true for temporary squatter kampung (Tunas and Peresthu, 2010). The urban poor are forced to work for low wages and live in the sprawling slums and squatter settlements, usually encroaching the river basins in the cities.

Yogyakarta is a city where slums at the riverside have been in existence for many years (Setiawan, 2002). There are three rivers crossing the city, creating overcrowded settlements on their flood plains. Slum areas (also called kampung) have attracted migrants to occupy pieces of land with low cost. However, beginning in the 1990s the price of land started to increase, and commercialization of spaces in slums areas flourished.

Slums and squatters find their ways to river basins. People have been overcrowding the riverside. Extensive impervious surfaces, which increase runoff response to rainfall, and ecological pressure by people dwelling at the riverside always threat the urban inhabitants with floods and polluted water sources. Eutrophication and degraded aquatic ecosystem are pervasive issues concerning urban rivers in Yogyakarta. Waterborne and water-deprived diseases (such as diarrhea, dysentery, skin infections and conjunctivitis) and water-related diseases, such as rodent-borne leptospirosis (Sakundarno et al., 2014) are endemic in neighborhoods of the river basins. Due to poorly 
constructed houses built along the river flood plains, pneumonia and tuberculosis, associated with overcrowding, poor ventilation and lack of natural light, are more frequently encountered.

Urban development in Indonesia has taken into consideration how kampung could be upgraded focusing on better roads, pathways, water supplies, storm water drainage, waste disposal and other infrastructure to support productive socio-economic activities of the people living in the slum areas (Minnery et al., 2013). Kampung Improvement Program was implemented in 1969 (in Jakarta), however, the program did not sustainably improve the social and economic conditions of the kampung inhabitants. Other related programs, such as Healthy River Project (Projek Kali Bersih), Urban Settlement Improvement Project (Projek Penyehatan Lingkungan Pemukiman Kota), Environment and Settlement Health Improvement Project (Projek Peningkatan Kesehatan Lingkungan dan Pemukiman), failed to initiate sustained improvement of the physical, biological and social environment for people living in slums and squatters along the urban rivers.

Until recently development activities to improve slums and squatters in the river basin areas are usually project-based, often donor-driven, and with limited involvement of people living in the areas (Firman, 2004). Beneficiaries of the projects are usually poor, working in the informal sectors, and often without legal status over their settlements. As part of project planning, communities are usually involved in consultation processes (such as focus group discussions or in person interviews), while more time-consuming community engagement has never been done.

Community engagement is known as a process of involving community members and the reliance on resources owned by the communities as the foundation for designing, implementing, and evaluating solutions to problematic conditions that affect them. Even when hard engineering is successful in solving environmental problems, behavioral change at the individual, household and community levels are essential in improving the environment (Bell et al., 2013).

People living along riverside, many of them constructed semi-permanent or permanent buildings to stay on the rivers' banks or flood plains, may be involved in constructive participation to create a river improvement plan that is technically sound, economically attractive and generally understood and preferred by those affected by the plan. Zhu (2015) indicated that the success of community engagement was enhanced by social milieu (level of social cohesion) and physical environment (communal space). The main objective of this study is to know the level and variability of engagement among people living at the river basins with activities to improve the structure, functioning and quality of the urban river.

\section{EXPERIMENTAL METHOD}

In person interviews, focus group discussion and direct observations were carried out to know the extent and variability of engagement levels with improvement of three urban rivers in Yogyakarta city, among people living at the riverside. Informants of this study were heads and informal leaders of Rukun Tetangga or RT (neighborhood association) and Rukun Warga or RW (community association), tenants (of cheap rental rooms or houses), and owners of legal or illegal estates along the rivers' banks and flood plain.

Data analyses included various techniques, especially pattern-matching and explanation building based on data collected from multiple sources, aiming at optimal triangulation processes (examining and establishing validity of the study). Peer debriefing (data assessment by peers to enhance the credibility of the study), member checking (informant feedback or validation), reflexivity (examining the researcher's role in the process and outcomes of research) and thick description (providing cultural context and meaning that people place on actions and things) were techniques, beside triangulation, to ensure rigor of case study data analyses and interpretation.

\section{RESULTS AND DISCUSSION}

Development of river basins in Yogyakarta was initially meant to maintain the river channel through the construction of hard banks. Channel realignment and shape changes may reduce erosion and prevent flooding. Ideally a river should be left on its own rein, without maintenance works, such as bank repairs. However, due to potential damage to riparian property and infrastructure, hard engineering solutions lead by the government have been implemented with no or minimal consultations involving the communities who lived along the rivers.

Romo Mangun (a catholic priest, award winning writer and architect, and human right activist), who lived for 6 years among slum dwellers along the Code River, was an advocate for riverside society, transforming the life of the people from vdestitutes to descent informal and formal 


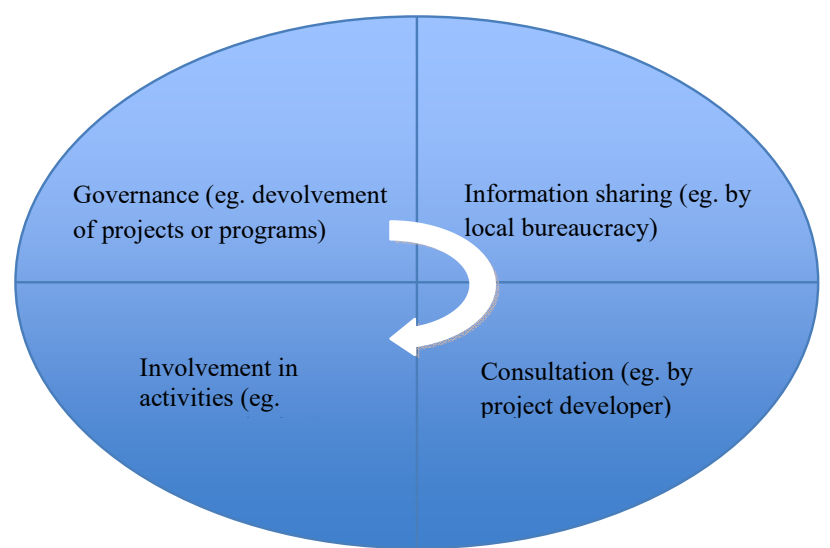

Figure 1. Levels of community engagement

workers with better social and family lives. The settlement along Code River was uplifted to become lively colorful houses, built with affordable materials (Widodo, 2012). The riverside community were fully engaged in social, cultural and educational activities, including efforts to keep the river clean.

Inspired by the Code riverside community led by Romo Mangun, community-based development to improve the structure, functioning and quality of urban rivers has gained better acceptance in Yogyakarta. Communities who lived along Gajah Wong River engaged in the construction of communal water treatment plan, development of waste disposal facilities and commitment to free Gajah Wong River from trash or domestic waste. The initiatives were led by local bureaucracies, in collaboration with other stakeholders, including companies such as Martha Tilaar Group, PT Gramedia, PT Prodia, Affandi Foundation, Kehati Foundation and Rotary Club of Yogyakarta District.

A group of young architects (known as ARKOM or Community Architects) played pivotal roles in small-scale project involving the local communities, such as building Balai Warga (Community Hall) at the riverside of Winongo River. ARKOM established a community called Kalijawi (Winongo and Gajah Wong communities) to maintain development from below, where communities at the grass-root level continuously learn how to make a better neighborhood and their habitat along the riverside. ARKOM and the communities who live at the Winongo riverside always put pressure on the local government to involve the communities in any policy regarding the restoration or rehabilitation of urban rivers in Yogyakarta, and consider the river as an integral part of the communities living in the riverside.
Towards the end of the 1980s, the flood plain of Code River was fully occupied by urban squatters who remain poor until now. Similarly, Gajah Wong and Winongo Rivers have seen rapid development of semi-permanent or permanent houses, although changes did not occur as quickly as those in Code riverside. Small areas of open space are found along the banks of the two rivers, which could be maintained as ecological oasis in the densely populated areas of the city.

The hard engineering or ecological approaches in restoration, rehabilitation or improvement of urban rivers in Yogyakarta left people who live along urban riverside to be even more marginalized and driven away from their already meager living.

Socially oriented development to improve urban rivers needs community engagement, to ensure warm, welcoming, and productive reciprocity, which consolidates the social lives of people living in the slum areas and at the same time uplifts the ecosystem functioning of urban rivers. At least there are 4 levels of community engagement, practiced among the riverside communities in Yogyakarta: better knowledge through information sharing, participation through public consultation, involvement in activities, and governance in community projects or programs (Figure 1).

Development of urban rivers and the riverside communities should transform poor and marginalized people, who live at the risk of floods and diseases due to the absence of basic hygiene and sanitation, into descent neighborhood with more opportunities to earn a living. These efforts could not be done without active involvement of the people themselves under mentoring or coaching of various experts. Community engagement need effective learning processes over time, when empowered communities are capable to direct, plan and implement their own trajectories to more 
equitable and prosperous neighborhood, as an integral well-functioning ecosystem of urban rivers.

\section{CONCLUSION}

Hard engineering solutions and ecological approaches of urban river restoration seem to marginalize poverty-ridden riverside communities who could not afford urban housings, but slums and squatters encroaching river banks and flood plains. Community engagement has become an acceptable approach in the development of urban rivers. Information sharing and public consultation increase community participation, but still fall short of transforming the livelihood of the communities to decent social standing. Mentoring and coaching by experts are needed initially so that the communities could actively engage with their own social and economic improvement, while contributing to clean and well-functioning ecosystem.

\section{REFERENCES}

Bell, K.B., Lindenfeld, L., Speers, A.E., Teisl, M.F., and Leahy, J.E., Creating Opportunity for Improving Lake-Focused Stakeholder Engagement: Knowledge-Action Systems, Pro-Environment Behavior and Sustainable Lake Management. Lakes \& Reservoirs: Research and Management, 18:5-14.

Firman, T., 2004. Major Issues in Indonesia's Urban Land Development. Land Use Policy ,21:347-355.

Frazer, L., 2005. Paving Paradise: The Peril of Impervious Surfaces. Environmental Health Perspectives, 114(1):A21.

Lange, C., Schneider, M., Mutz, M., Haustein, M., Halle, M., Seidel, M., Sieker, H., Wolter, C.,
Hinkelmann, R., 2015. Model-Based Design for Restoration of A Small Urban River. Journal of Hydro-environment Research, 9(2):226-236.

Lu, Y., 2010. Rural-Urban Migration and Health: Evidence from Longitudinal Data in Indonesia. Social Science and Medicine, 70(3):412-419.

Minnery, J., Argo, T., Winarso, H., Hau, D., Veneracion, C.C., Forbes, D., and Childs, I., 2013. Slum Upgrading and Urban Governance: Case Studies in Three South East Asian Cities. Habitat International, 39:162-169.

Sakundarno, M., Bertolatti, D., Maycock, B., Spickett, J., and Dhaliwai, S., 2014. Risk Factors for Leptospirosis Infection in Humans and Implications for Public Health Intervention in Indonesia and the Asia-Pacific Region. Asia Pacific Journal of Public Health, 26(1):15-32.

Setiawan, B., 2002. Community Initiatives and Involvement in Creating Healthy and Friendly Cities: Lessons from Yogyakarta, Jurnal Manusia dan Lingkungan, 9(1):1-15.

Tinglanchali, T., 2012. Urban Flood Disaster Management, Procedia Engineering, 32(1):25-37.

Tunas, D., and Peresthu A., 2010. The Self-Help Housing in Indonesia: The Only Option for The Poor? Habitat International, 34:315-322.

Widodo, J., 2012. Urban Environment and Human Behavior: Learning from History and Local Wisdom. Procedia, 42:6-11.

Zhu, Y., 2015. Toward Community Engagement: Can The Built Environment Help? Grassroots Participation and Communal Space in Chinese Urban Communities. Habitat International, 46:44-53. 